\section{Short-day Photoperiod Duration Influences Splitting of Poinsettia}

\author{
Virginia Zrebiec $^{1}$ and Harry K. Tayama ${ }^{2}$ \\ Department of Horticulture, The Ohio State University, Ohio Agricultural \\ Research and Development Center, Wooster, $\mathrm{OH} 44691$
}

Additional index words. Euphorbia pulcherrima, flowering, flower initiation, flowering disorder

Splitting is a physiological flowering disorder of poinsettia (Euphorbia pulcherrima Willd. ex K1.) in which the vegetative shoot tip becomes reproductive under long-day (LD; noninductive) photoperiods (Tayama et al., 1982). Vegetative axillary shoots, usually three, develop around the apical flower bud. This results in the splitting of the main stem into three, which destroys the desired singlestemmed habit of the plants. Splitting can occur any time during the production cycle, affecting stock plants or cuttings. The severity of splitting varies from year to year, and even within a greenhouse.

Working with 'Paul Mikkelsen', Kofranek and Hackett (1965; Hackett and Kofranek, 1971) found that maintaining plants under long days (16 hr) and cool nights (15C) did not reduce splitting. Raising the night temperature to $25 \mathrm{C}$ with $\mathrm{LD}$ conditions, however, did reduce splitting. They also found that $100 \%$ splitting occurred after exposure to 3 short days (SD) followed by LD at 21C (Hackett and Kofranek, 1971). Struckmeyer and Beck (1960), working with the cultivar 'Ruth Ecke' (night temperatures not given), reported that splitting was induced by subjecting plants to $8 \mathrm{SD}$ followed by $30 \mathrm{LD}$.

We evaluated splitting in 'Annette Hegg Dark Red' poinsettia, a cultivar susceptible to this phenomenon, by determining 1) the minimum number of SD required to induce splitting, and 2) the number of leaves formed and the length of time from the start of SD treatment until a flower bud was visible.

Physiologically and genetically uniform rooted cuttings were obtained and grown under LD. Plants were severely pruned three times in succession, each time allowing only one axillary bud to remain per shoot. Cuttings from axillary shoots arising from the third pruning that were similar in age, length, and size were harvested for our experiments.

Short days required for splitting. Cuttings were rooted and planted in $475-\mathrm{cm}^{3}$ pots and maintained under noninductive conditions for

Received for publication 30 Jan. 1989. Salaries and research support provided by state and federal funds appropriated to the Ohio Agricultural Research and Development Center, The Ohio State Univ. Manuscript no. 16-89. Support also received from Paul Ecke Poinsettias, Encinitas, Calif. The cost of publishing this paper was defrayed in part by the payment of page charges. Under postal regulations, this paper therefore must be hereby marked advertisement solely to indicate this fact.

${ }^{\mathrm{I}}$ Former Senior Laboratory Demonstrator. ${ }^{2}$ Professor.
10 days. On 10 June 1985, they were placed in an inductive condition for $0,1,3,5,7$, 9 , and $11 \mathrm{SD}$, after which they were returned to LD. There were 24 plants per treatment. Short days were provided by covering plants with black opaque cloth from 4:30 PM to 7:30 AM. Long days were naturally occurring. Between 10 June and 12 Aug., plants were examined weekly for initial symptoms of splitting, i.e., the appearance of flower buds. Greenhouse temperatures typically were 18 to $24 \mathrm{C}$ at night.

The first flower bud was visible 26 days after the start of SD. Flower buds of the last plants to respond were visible 33 days after the start of SD, and these plants were from the three- and five-SD groups. All plants from the 0 - and 1-SD groups remained vegetative until the termination of the study, 63 days after the start of SD. Fifteen of the 24 plants receiving $3 \mathrm{SD}$ initiated a flower bud. All plants in treatments receiving 5 through 11 SD split. Five SD were minimum for $100 \%$ splitting of plants within a treatment, while some splitting was evident after $3 \mathrm{SD}$. This compares with the 3-SD minimum reported by Hackett and Kofranek (1971) in 'Paul Mikkelsen' and 8-SD minimum reported by Struckmeyer and Beck (1960) in 'Ruth Ecke'.

Relation of splitting to number of leaves formed. Two sets of this experiment were conducted to determine the number of leaves formed and the length of time from the start of SD until the appearance of splitting. Cuttings were taken from stock plants on 13 Nov. 1985 and 21 Feb. 1986. There were 20 plants in the first set and 15 in the second. Following LD exposure, plants received 5 SD beginning 5 Feb. and 24 Mar., respectively, followed by LD exposure. The uppermost unfolded leaf on each plant was marked at the start of SD. Plants were examined weekly for the appearance of a flower bud. The number of leaves that unfolded after the start of SD and the number of days that elapsed for each plant were recorded.

Splitting was evident 40 to 47 days after the start of SD in set 1. An average of 10.2 leaves had unfolded, ranging between nine and 11 per plant, when splitting became visible. In set 2 , splitting was observed 28 days after the start of SD. Plants in this set also displayed an unfolding of nine to 11 leaves, but there was an average of only 9.2 leaves unfolded per plant (Table 1).

To summarize: 1) plants from heavily pruned stock plants within a single treatment showed uniform splitting responses; 2) 100\% splitting was induced in 'Annette Hegg Dark Red' plants when five or more inductive SD interrupted LD (noninductive) conditions; splitting was induced in $\approx 60 \%$ of the plants after a 3-day interruption and $0 \%$ after a 1day or no interruption; 3) nine to 11 leaves unfolded from the start of SD treatment until a flower bud was visible; and 4) 26 to 47 days elapsed from the start of SD conditions until a flower bud was evident, depending on the growing season.

Despite the differences in time between the initiation of SD and the appearance of flower buds in these studies, the number of leaves that expanded during the interval remained relatively constant. Siraj-Ali (1988) found that cuttings that were more physiologically mature flowered in fewer days than those that were physiologically juvenile. Perhaps a similar phenomenon exists between maturity level and the number of leaf primordia that are present at the time the "triggering" flowering stimulus (e.g., SD, growth regulator, temperature) is experienced. Leaf count might be a superior measure for evaluating the relative effects of these stimuli or the relative level of plant maturity compared to "days to split", in that it would appear to be less prone to deviation because of environmental growing conditions.

Table 1. Observations of inducted splitting of 'Annette Hegg Dark Red' poinsettia for two sets of plants.

\begin{tabular}{|c|c|c|}
\hline $\begin{array}{l}\text { Activity or } \\
\text { criterion }^{2}\end{array}$ & Set 1 & Set 2 \\
\hline Date propagated & 13 Nov. & 21 Feb. \\
\hline $\begin{array}{l}\text { Date transplanted to } \\
475-\mathrm{cm}^{3} \text { pots }\end{array}$ & 2 Dec. & 14 Mar. \\
\hline $\begin{array}{l}\text { Starting date of } 5 \text {-day } \\
\text { SD treatment to induce } \\
\text { splitting }\end{array}$ & 5 Feb. & 24 Mar. \\
\hline $\begin{array}{l}\text { Weeks to visible splitting } \\
\text { (after initiation of SD) }\end{array}$ & $6-7$ & 24 IVrad. \\
\hline Split $(\%)$ & 95 & 80 \\
\hline $\begin{array}{l}\text { Mean no. of leaves } \\
\text { formed from SD to } \\
\text { visible split } \\
\text { SD of no. of leaves }\end{array}$ & $\begin{array}{l}10.2 \\
0.54\end{array}$ & $\begin{array}{l}9.3 \\
0.62\end{array}$ \\
\hline
\end{tabular}

${ }^{\mathrm{z}} \mathrm{SD}=$ short day.

\section{Literature Cited}

Guttridge, C.S. 1963. Inhibition of flowering in poinsettia by gibberellic acid. Nature (London) 197:920-921.

Hackett, W.P. and A.M. Kofranek. 1971. Analy sis of low temperature stimulation of floral initiation in poinsettia cv. 'Paul Mikkelsen'. J. Amer. Hort. Sci. 96:308-311.

Kofranek, A.M. and W.P. Hackett. 1965. The influence of daylength and night temperature on the flowering of poinsettia cv. Paul Mikkelsen. Proc. Amer. Soc. Hort. Sci. 87:515-520.

Siraj-Ali, Y. 1988. The identification of developmental phases in ooinsettia and the relationship to non-photoperiodic flower bud initiation. PhD Diss., The Ohio State Univ., Columbus.

Struckmeyer, B.E. and G.E. Beck. 1960. Flower bud initiation and development in poinsettia (Euphorbia pulcherrima Willd.) Proc. Amer. Soc. Hort. Sci. 75:730-738.

Tayama, H.K., C.C. Powell, and Richard K. Lindquist. 1982. Quality poinsettias-fundamentals-1982. Ohio Florists' Assn. Bul. 633:1-3. 